\title{
Socio-economic, clinical and biological risk factors for mother - to - child transmission of HIV-1 in Muhima health centre (Rwanda): a prospective cohort study
}

Maurice Bucagu ${ }^{1 *}$, Jean de Dieu Bizimana² ${ }^{2}$ John Muganda ${ }^{3}$ and Claire Perrine Humblet ${ }^{4}$

\begin{abstract}
Background: Three decades since the first HIV-1 infected patients in Rwanda were identified in 1983; the Acquired Immunodeficiency Syndrome epidemic has had a devastating history and is still a major public health challenge in the country. This study was aimed at assessing socioeconomic, clinical and biological risk factors for mother - to child transmission of HIV- in Muhima health centre (Kigali/Rwanda).

Methods: The prospective cohort study was conducted at Muhima Health centre (Kigali/Rwanda).

During the study period (May 2007 - April 2010), of 8,669 pregnant women who attended antenatal visits and screened for HIV-1, 736 tested HIV-1 positive and among them 700 were eligible study participants. Hemoglobin, CD4 count and viral load tests were performed for participant mothers and HIV-1 testing using DNA PCR technique for infants.

Follow up data for eligible mother-infant pairs were obtained from women themselves and log books in Muhima health centre and maternity, using a structured questionnaire.

Predictors of mother-to-child transmission of HIV-1 were assessed by multivariable logistic regression analysis.

Results: Among the 679 exposed and followed-up infants, HIV-1 status was significantly associated with disclosure of HIV status to partner both at 6 weeks of age (non-disclosure of HIV status, adjusted odds ratio [AOR] 4.68, Cl 1.39 to 15.77, $\mathrm{p}<0.05$; compared to disclosure) and at 6 months of age (non-disclosure of HIV status, AOR, 3.41, Cl 1.09 to $10.65, p<0.05$, compared to disclosure).

A significant association between mother's viral load (HIV-1 RNA) and infant HIV-1 status was found both at 6 weeks of age ( $>=1000$ copies $/ \mathrm{ml}$, AOR 7.30, Cl 2.65 to 20.08, $\mathrm{p}<0.01$, compared to $<1000$ copies $/ \mathrm{ml}$ ) and at 6 months of age ( $>=1000$ copies $/ \mathrm{ml}$, AOR 4.60, Cl 1.84 to $11.49, \mathrm{p}<0.01$, compared to $<1000$ copies $/ \mathrm{ml}$ ).

Conclusion: In this study, the most relevant factors independently associated with increased risk of mother - to child transmission of HIV-1 included non-disclosure of HIV status to partner and high HIV-1 RNA. Members of this cohort also showed socioeconomic inequalities, with unmarried status carrying higher risk of undisclosed HIV status. The monitoring of maternal HIV-1 RNA level might be considered as a routinely used test to assess the risk of transmission with the goal of achieving viral suppression as critical for elimination of pediatric HIV, particularly in breastfeeding populations.
\end{abstract}

Keywords: Socioeconomic, Clinical and biological risk factors, HIV-1, Mother - to - child transmission, Cohort, Muhima/Rwanda

\footnotetext{
* Correspondence: bucagum@who.int

${ }^{1}$ World Health Organization Department of Maternal, Newborn, Child and Adolescent Health, 20, Avenue Appia, CH - 1211, Geneva 27, Switzerland Full list of author information is available at the end of the article
} 


\section{Background}

Three decades since the first HIV-1 infected patients in Rwanda were identified (1983), the Acquired Immunodeficiency Syndrome (AIDS) epidemic has had a devastating history and is still a major public health challenge in country $[1,2]$.

At the end of 2010, an estimated 34 million people [31.6 million-35.2 million] were living with HIV worldwide, up $17 \%$ from 2001. The proportion of women among people living with HIV has remained stable at 50\% globally, but they are more affected in Sub-Saharan Africa (59\% of all people living with HIV). Mother-to-child transmission of HIV remains the primary mode of child contamination during pregnancy, childbirth or breastfeeding. It is estimated that every day there are over 1,000 new HIV infections in children, with vast majority occurring in Sub-Saharan Africa. Nearly 370,000 [230,000 - 510,000] children were infected with HIV through mother- tochild transmission globally in 2009. The scaling up of effective interventions for the prevention of HIV transmission from mother- to- child (PMTCT) is still limited because of inadequate access to antenatal and postnatal services, particularly in developing countries [3].

With a population of 10.4 million (2010), of whom majority are female (52\%), young (67\% have less than 25 years) and living in rural areas (83\%), Rwanda faces enormous challenges of political, social, economic, health development, and particularly those relating to the consequences of the 1994 genocide. Its gross domestic product is estimated at USD 540 \$/capita (2010), with a high level of poverty (56.9\% below the poverty line, 2005) [4]. HIV trend from Rwanda Demographic and Health surveys data shows that adult HIV prevalence has remained unchanged from 2005 to 2010. Estimated nationally at 3\%, 4\% in women and $2 \%$ in men, it is $8.7 \%$ in urban areas and $2.8 \%$ in rural areas (2010) [5].

The programme for prevention of mother-to-child transmission of HIV-1 was put in place in 1999, with a goal of reducing the incidence of new HIV infections among children born to HIV positive mothers, with the use of antiretroviral medicines [6,7]. The package of PMTCT services provided during the study period (2007-2010) included antenatal care with testing and counseling; essential obstetric and neonatal care; triple therapy and dual therapy ARV respectively for HIV-positive mothers and infants; as well as family planning [8]. Country's commitments, towards eliminating new HIV infections among children by 2015 and keeping their mothers alive, are in line with the global plan launched by the UN Secretary General in 2011. The following specific targets were defined at global level: overall transmission rate $<5 \%$ at the population level $(<2 \%$ in the absence of breastfeeding or measured at 6 weeks) and the reduction of new pediatric HIV infections by $90 \%$ from the estimated baseline [9].
In developed countries, the rate of HIV transmission from the mother to the child has been significantly reduced to $1 \%$, through the use of antiretroviral triple therapy for HIV-infected mother, caesarean delivery and formula feeding for the child. In Rwanda, the mother-tochild transmission of HIV-1 before the era of antiretroviral medicines, has affected more than one in four children (25.7\%) born to HIV-1 positive mothers [2].

During the decade of 2000s, the use of antiretroviral drugs allowed for significant advance in the reduction of HIV mother-to-child transmission. However, feeding practices for exposed children still represent a major challenge for populations with breastfeeding as the only feeding alternative for child survival. Nearly all Rwandan children are breastfed through the first year of life, with about $70 \%$ of them receiving complementary foods by age of 6 to 9 months [5].

Several studies support the role of socioeconomic, clinical and biological risk factors for HIV-1 transmission [8-12]. Based on this background, we initiated this study to assess the role of socioeconomic, clinical and biological factors in mother-to-child transmission of HIV-1 at Muhima health centre (Kigali/Rwanda), where this type of study has never been conducted. The site of the study includes Muhima health centre \& hospital, located in the district of Nyarugenge (Kigali), with a population of about 287,529 inhabitants (2010).

This study is specifically expected to allow for better understanding of risk factors, likely to limit the effectiveness of the national strategy for elimination of mother-to-child transmission of HIV-1. The knowledge generated from this study in Muhima will guide the national evidence-based response towards a multisectoral approach, with both more effective health interventions and specific socioeconomic strategies to address the HIV pandemic in Rwanda [1,9,13].

\section{Methods}

\section{Study design and population}

The prospective cohort study was conducted at Muhima health centre (Kigali/Rwanda).

All pregnant women diagnosed with HIV-1 and attending PMTCT service at Muhima health centre were invited to participate in the study, between May 2007 and April 2010. Eligible study participants were pregnant HIV-1 infected women, consenting to the study, who had attended antenatal visits or delivered at Muhima maternity and had benefited from PMTCT interventions in line with the national guidelines (based on combination of Zidovudine/ Lamivudine/Nevirapine for mothers during pregnancy, childbirth and postnatal period and Nevirapine/Zidovudine for newborn). Additional inclusion criteria was for participants to be registered as residents within the specific catchment area of Muhima health centre and therefore 
expected to attend the postnatal follow up as required. All HIV negative pregnant women, those whose consent to the study was not obtained and those living outside the catchment area of Muhima were excluded from the study.

We estimated the sample size based on anticipated HIV-1 infection of $4 \%$ at 6 weeks and absolute precision in $\%$ points of 1.5 , with a confidence interval (CI) of $95 \%$. A sample size of 656 was the minimum number required for the study. During the study period, of 8,669 pregnant women who attended antenatal visits and screened for HIV-1 in Muhima health centre, 736 tested HIV-1 positive and among them 700 were eligible study participants [14]. At enrolment, eligible participants were interviewed by three trained PMTCT providers (2 data collectors supervised by 1 medical doctor) until the determined sample size of 700 women was reached. Information was collected from each mother - infant pair for a period of 6 months after childbirth, including specific socioeconomic characteristics, clinical and biological features. For twins, one member randomly selected from each twin pair was included in the study.

\section{Data collection and management}

Follow up data for eligible mother-infant pairs, about pregnancy, childbirth and postnatal period were obtained from women themselves and log books in Muhima health centre and maternity, using a structured questionnaire, translated into Kinyarwanda by the principal investigator. Those data included medical records and laboratory tests results. As viral load was not a requirement for the national PMTCT protocol, it was performed by the Rwanda National Referral laboratory for study participants at the request of the author, using COBAS TaqMan HIV-1 test or Amplicor HIV-1 Monitor test v1.5 (both from Roche Diagnostic Corporation, Indianapolis, IN). This is nucleic acid amplification test for the quantification of Human Immunodeficiency Virus Type 1 RNA in human plasma.

Required data were collected anonymously, using participant's unique identifier, nationally provided by the National Centre for Treatment and Research on AIDS, Malaria, Tuberculosis and other epidemics (Rwanda TRAC plus/Rwanda Ministry of Health).

The study was designed to allow for periodic requestioning of study participants, at birth, 6 weeks and 7 months postpartum, 1 month after cessation of breastfeeding as per the national guidelines [1].

Twenty -one study participants were considered lost to follow up as they have not shown up for regular visits and the study team unable to find HIV-1 tests results for their infants at 6 weeks and/or at 6 months (Dried Blood Spot method using PCR technique). Baseline data on known variables, namely age, marital status, maternal education, residence, wealth index were found to be sufficiently similar to those of participants (679) who remained in the study $[15,16]$.

The data were double entered for all 700 questionnaires, by a team of 2 data entry clerks supervised by a lecturer from the University of Rwanda/School of Public Health.

Data quality assessment was performed in two steps: A review of all the records for participants with caesarean section as mode of delivery (121 cases) was conducted: $90 \%$ of self-reports were confirmed by relevant medical records. Information on mode of delivery, in this study, was provided by the participant and confirmed with the maternal health card. The quality control was meant for checking data consistency between the study questionnaires and medical records from the health facility where childbirth took place. For 12 participants in the study (i.e. 10\%), expected data were not found in the Muhima hospital register. The missing medical records were later found in a logbook that was kept in the Kigali University Hospital (CHUK). The logbook was taken by the CHUK team, when it went back to its premises after rehabilitation (2009) and temporary relocation in Muhima hospital (the study site) in 2007-2008.

In addition, all viral load tests results for 679 study participants were jointly verified by the principal investigator and the laboratory manager, before the required payment could be executed by Muhima hospital.

The main outcome was cumulative incidence of mother - to - child transmission of HIV-1. It was measured at 6 weeks and 6 months of life among live born children $[17,18]$.

\section{Data analysis}

Background data were summarized with descriptive statistics. Univariate analyses of associations were performed using the chi squared test, Fisher's test as appropriate. Potential risk factors for mother - to - child transmission of HIV-1 were considered as covariates, including: socioeconomic characteristics that included mother's age in years $(<=24$ years $>24$ years); marital status (married/unmarried); mother's education (no education/primary education; secondary school and more); parity (primiparous/multiparous); wealth index recategorized in 5 quintiles (poorest/second/middle/ fourth/richest) (Demographic Health Survey wealth index model); disclosed HIV status to partner (yes/ no); sex of infant (male, female), infant feeding choices during the first 6 months of life (exclusive breastfeeding/artificial feeding/mixed feeding) [19].

Clinical factors were: mode of delivery (vaginal/instrument assisted/cesarean section); type of ARV treatment (prophylactic/curative); duration of ARV treatment prior to delivery ( $<6$ weeks $/>=6$ weeks).

Biological factors included hemoglobin during pregnancy $(<11 \mathrm{~g} / \mathrm{dl} />=11 \mathrm{~g} / \mathrm{dl}) ; \mathrm{CD} 4$ count $(<350$ cells $/$ 
$\mu \mathrm{L} />=350$ cells $/ \mu \mathrm{L})$; viral load (HIV-1 RNA) $(<1000$ copies $/ \mathrm{mL} />=1.000$ copies $/ \mathrm{mL}$ ).

Predictors of mother-to-child transmission of HIV-1 were assessed by multivariable logistic regression. All variables with potential association with the main outcome - HIV-1 transmission, were entered into the logistic regression model. Hosmer and Lemeshow test was applied to check for how well the model fit. Variables were held in the model if they reached a significance level of $\mathrm{P}<0.05$.

In addition, to demonstrate the potential mediation effect of HIV disclosure variable through which a focal independent variable (marital status) is able to influence the dependent variable (infant HIV status), as shown in Figure 1, the following steps were tested, as applied in social psychological research: first the independent variable affects the mediator in the first equation; second, the independent variable affects the dependent variable in the second equation; and third, the mediator affects the dependent variable in the third equation.

A series of regression models was used to quantify the relationships between marital status and HIV status disclosure (a); marital status and infant HIV status (b), HIV status disclosure and infant HIV status (c) [20-23].

Statistical analyses were performed with STATA 12.0 (Stata Corp, College Station, TX) and Statistical Package for the Social Sciences (SPSS) version 17.

\section{Ethical considerations}

The study protocol was reviewed and approved by the Rwanda national ethical committee and the research commission of University Teaching Hospital of Kigali, in February 2007, with annual evaluation of the study progress. An informed consent has been obtained, with a written and signed document, for each participant in this cohort study.

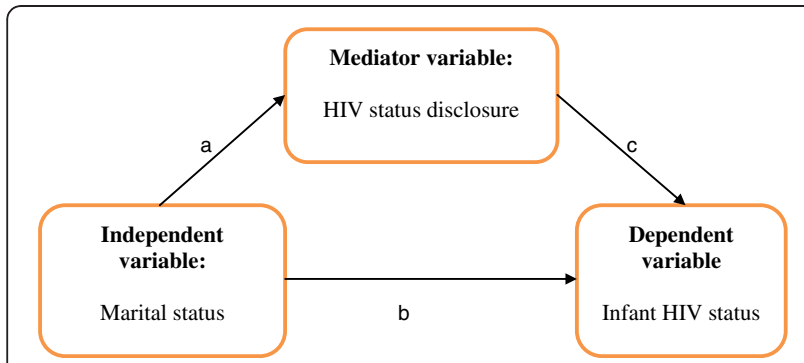

Figure 1 Path diagram for mediation effect of HIV status disclosure. Mothers and infants meeting inclusion criteria in the study. Muhima health centre cohort, Kigali/Rwanda, 2007-2010 [21]. The following steps were tested, as applied in social psychological research: first the independent variable affects the mediator in the first equation (a); second, the independent variable affects the dependent variable in the second equation (b); and third, the mediator affects the dependent variable in the third equation (c).

\section{Results}

Baseline characteristics

Socioeconomic, clinical and biological characteristics of mother-infant pairs enrolled in the study are shown in Table 1 . Nearly 1 in 3 mothers (29.7\%) were young, with a median age of 27 years (range: 17 - 45 years). Majority of mothers had only primary or no education $(74.7 \%)$ and were married (82.7\%). Two in five (40.3\%) study participants were classified by wealth index quintiles as poorest and poor. Over one fifth $(21.5 \%)$ of women were primiparas, with median number of 2 births (range: 1-9 births). For $18.9 \%$ of women, male partner's HIV status was not disclosed. Only $2.9 \%$ of babies were born at home; for $17.8 \%$ of pregnant women, babies were delivered by cesarean section. Over half (50.7\%) of exposed infants were females. The vast majority (86.1\%) of mothers reported that their children received exclusive breastfeeding. At enrollment, the median hemoglobin was $12.20 \mathrm{~g} / \mathrm{dl}$ (range: 6.30 - $19 \mathrm{~g} / \mathrm{dl}$ ); with median CD4 count of 429.50 cells $/ \mathrm{mm}^{3}$ (range: $11-1718$ cells $/ \mathrm{mm}^{3}$ ) and median viral load of 40 copies/ml (range: 40 - 890,000 copies $/ \mathrm{ml}$ ); $63.3 \%$ of participant mothers had a viral load of less than 40 copies $/ \mathrm{ml}$. Of 679 mothers, majority $(51.8 \%)$ reported they have received HIV chemoprophylaxis regimen and $77.5 \%$ have taken ARVs for at least 6 weeks prior to childbirth.

\section{Infant HIV-1 infection}

The study enrolled a cohort of 700 HIV-1 infected pregnant women and their newborn. Of these 21 study participants were lost to follow up and 679 pregnant women had live births of 674 single babies and 10 twins (Figure 2). At 6 weeks, of the 679 live born babies and followed up, a total of 23 infants tested HIV-1 positive. Among these, at 6 months, 22 infants were confirmed HIV-1 infected and 1 infant uninfected with HIV. Among the 656 initially HIV-negative infants, 4 died before 6 months of age (with no confirmed diagnosis). Of the 652 remaining infants, 3 were confirmed HIV-1 infected between 6 weeks and 6 months of age $(11.5 \%$ of all infected infants). The overall HIV-1 cumulative incidence of mother - to - child transmission rate was $3.7 \%$ at 6 weeks to 6 months of age and 3.2\% was at zero to 6 weeks of age.

Risk factors for mother-to-child transmission of HIV-1 In univariate analysis, among the 679 HIV exposed live infants, there is a statistically significant association between HIV-1 status of infants and their mothers' marital status; parity; hemoglobin level, duration of ARV treatment, CD4 count and viral load, as well as HIV status disclosure to partner and infant feeding choices. Variables not associated with HIV-1 status of infants included mother's age, mother's education, wealth, mode 
Table 1 Background characteristics of mothers and infants meeting inclusion criteria in the study

\begin{tabular}{|c|c|c|}
\hline Variable & Number ( $N=679)$ & Percentage \\
\hline \multicolumn{3}{|l|}{ Mother's age in years } \\
\hline$<=24$ & 202 & 29.7 \\
\hline$>24$ & 477 & 70.3 \\
\hline \multicolumn{3}{|l|}{ Marital status } \\
\hline married & 562 & 82.7 \\
\hline unmarried & 117 & 17.3 \\
\hline \multicolumn{3}{|l|}{ Mother's education } \\
\hline none/primary & 509 & 75.0 \\
\hline secondary/university & 170 & 25.0 \\
\hline \multicolumn{3}{|l|}{ Wealth } \\
\hline poorest & 175 & 25.8 \\
\hline poor & 99 & 14.5 \\
\hline middle & 143 & 21.1 \\
\hline rich & 145 & 21.4 \\
\hline richest & 117 & 17.2 \\
\hline \multicolumn{3}{|l|}{ Parity } \\
\hline primipara & 146 & 21.5 \\
\hline multiparous & 533 & 78.5 \\
\hline \multicolumn{3}{|c|}{ Disclosed HIV status to partner } \\
\hline Yes & 551 & 81.1 \\
\hline No & 128 & 18.9 \\
\hline \multicolumn{3}{|l|}{ Place of delivery } \\
\hline home & 20 & 2.9 \\
\hline facility & 659 & 97.1 \\
\hline \multicolumn{3}{|l|}{ Sex of infant } \\
\hline male & 335 & 49.3 \\
\hline female & 344 & 50.7 \\
\hline
\end{tabular}

Type of feeding during first 6 months of life

\begin{tabular}{lcc}
\hline exclusive breastfeeding & 585 & 86.1 \\
artificial feeding & 80 & 11.8 \\
mixed feeding & 14 & 2.1 \\
Mode of delivery & & \\
\hline $\begin{array}{l}\text { vaginal/instrument assisted } \\
\text { cesarean section }\end{array}$ & 1258 & 82.2 \\
Hemoglobin during pregnancy & & 17.8 \\
\hline$<11$ g/dl & 180 & 26.5 \\
$>=11$ g/dl & 499 & 73.5 \\
Type of ARV treatment & & \\
\hline $\begin{array}{l}\text { prophylactic } \\
\text { curative }\end{array}$ & 352 & 51.8 \\
$\begin{array}{l}\text { Duration of ARV treatment prior } \\
\text { to delivery }\end{array}$ & 327 & 48.2 \\
\hline less than 6 weeks & 153 & \\
6 weeks or more & 526 & 77.5
\end{tabular}

Table 1 Background characteristics of mothers and infants meeting inclusion criteria in the study (Continued)

\begin{tabular}{lll}
\hline CD4 count & & \\
\hline$<350$ cells $/ \mathrm{mm}^{3}$ & 263 & 38.7 \\
$>=350$ cells $/ \mathrm{mm}^{3}$ & 416 & 61.3 \\
Viral load & & \\
\hline$<1000$ copies/ml & 517 & 76.1 \\
$>=1000$ copies/ml & 162 & 23.9 \\
\hline Muhima health centre cohort, Kigali/Rwanda, 2007 - 2010.
\end{tabular}

and place of childbirth and type of ARV treatment (Table 2).

In a multivariable logistic regression analysis (Table 3), the most relevant variables that remained significant in the model included disclosure of HIV status to partner and viral load (HIV-1 RNA).

Among exposed infants, HIV-1 status was significantly associated with disclosure of HIV status to partner both at 6 weeks of age (non-disclosure of HIV status, adjusted odds ratio [AOR] 4.68, CI 1.39 to 15.77, $\mathrm{p}<0.05$; compared to disclosure) and at 6 months of age (non-disclosure of HIV status, AOR, 3.41, CI 1.09 to 10.65, p < 0.05, compared to disclosure).

A significant association between mother's viral load (HIV-1 RNA) and infant HIV-1 status was found both at 6 weeks of age $(>=1000$ copies $/ \mathrm{ml}$, AOR 7.30, CI 2.65 to $20.08, \mathrm{p}<0.01$, compared to $<1000$ copies $/ \mathrm{ml}$ ) and at 6 months of age ( $>=1000$ copies $/ \mathrm{ml}$, AOR 4.60, CI 1.84 to $11.49, \mathrm{p}<0.01$, compared to $<1000$ copies $/ \mathrm{ml}$ ).

In the study multivariable model, the following covariates were found with limited statistical significance: infant feeding choice at 6 months of age (mixed feeding, AOR 9.64, CI 0.96 to 96.62, p $<0.1$, compared to exclusive breastfeeding); mother's CD4 count both at 6 weeks of infant age $\left(<350\right.$ cells $/ \mathrm{mm}^{3}$, AOR 4.83, CI 0.98 to $23.90, \mathrm{p}<0.1$, compared to $>=350$ cells $\left./ \mathrm{mm}^{3}\right)$ and at 6 months of infant age $\left(<350\right.$ cells $/ \mathrm{mm}^{3}$, AOR 3.82, CI 0.92 to $15.94, \mathrm{p}<0.1$, compared to $>=350$ cells $/ \mathrm{mm}^{3}$ ); mother's hemoglobin level at 6 weeks of infant age $(<11 \mathrm{~g} / \mathrm{dl}$, AOR 2.58 , CI 0.90 to $7.40, \mathrm{p}<0.1$, compared to $>=11 \mathrm{~g} / \mathrm{dl})$.

\section{Discussion}

This study assessed socioeconomic, clinical and biological risk factors for mother - to - child transmission of HIV-1 among 679 infants (at 6 weeks) and 675 (at 6 months) born to HIV infected mothers and followed up at Muhima health centre (Kigali/Rwanda).

This vertical transmission occurs at three stages including prepartum, intrapartum and postpartum (breastfeeding) [24-26]. 


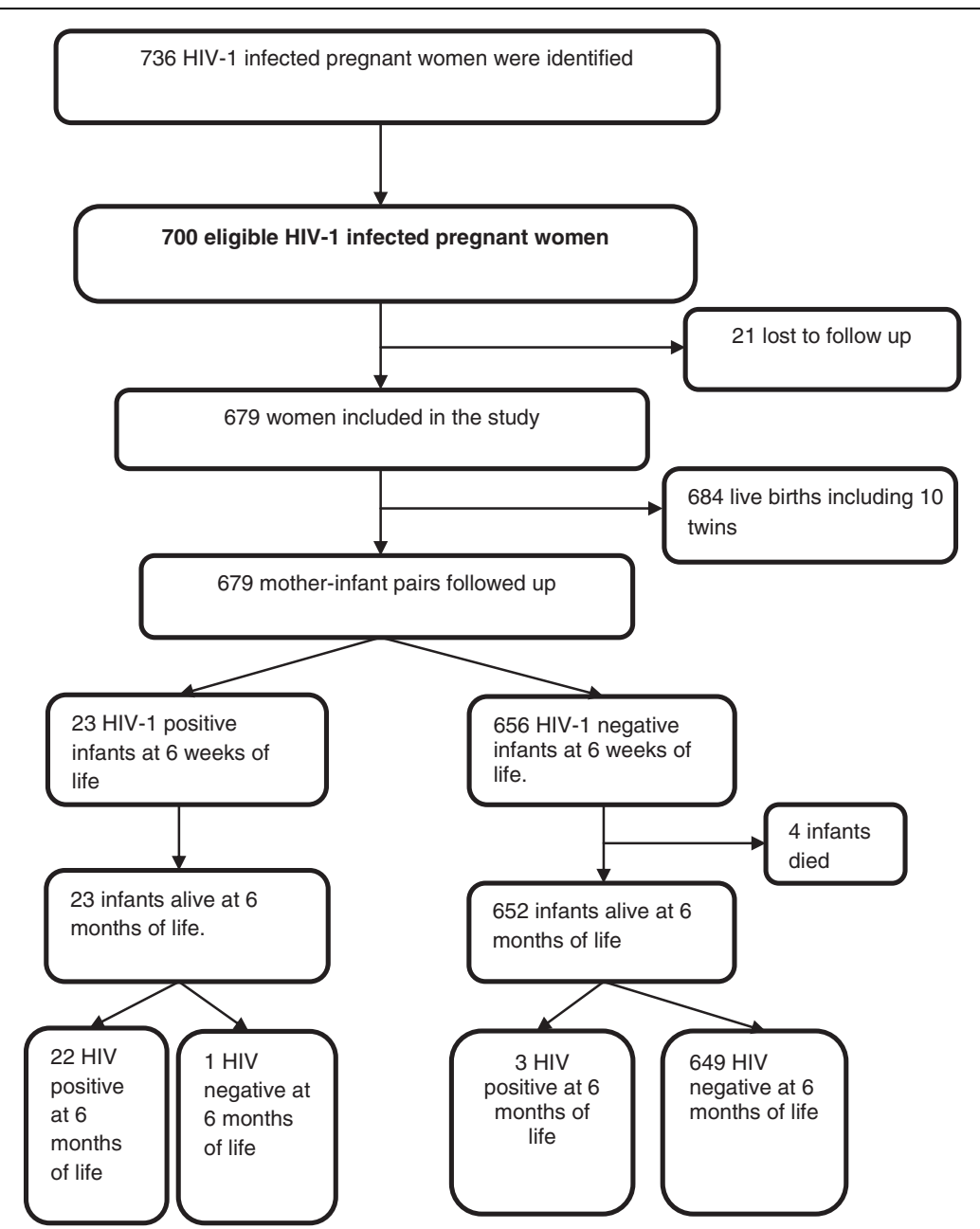

Figure 2 Muhima health centre cohort profile: mothers and infants meeting inclusion criteria in the study. Kigali/Rwanda, $2007-2010$.

In the Muhima cohort study, were most at risk of mother - to - child transmission, HIV-1 exposed infants whose mothers presented with no documented mutual disclosure of HIV status and a higher HIV-1 RNA level.

\section{Mutual disclosure of HIV status}

Consistent with other studies, non-disclosure of HIV status to partner emerged as an important factor for HIV-1 mother - to - child transmission in this cohort study.

Existing studies have increasingly shown disclosure as a way to encourage prevention and non-disclosure significantly associated with sexual risk behaviours.

Disclosure is of importance in PMTCT programmes as it allows an individual to get spousal or family support for preventive actions they may decide to undertake, including approaches for adequate ARV adherence [27-31].

Fear of stigma and rejection is thought to discourage disclosure [32].
Women appear to disclose, and to receive disclosure, more frequently than do men. Partner disclosure is also generally lower with casual partners than it is with steady partners.

A positive correlation between disclosure and social support has been documented in various contexts. Socioeconomic factors (education) and access to resources play an important role in influencing disclosure, with lower rates of disclosure associated with low-wage employment and economic vulnerability [33].

In Zimbabwe, receiving HIV education during antenatal visits at least twice and referral for psychosocial support were significantly protective [34] In Rwanda, a package of strategies - including couple counseling and community campaigns - seems to have overcome some barriers to disclosure [32].

From the social psychological analysis applied in this study, the required four conditions allowing for testing the validity of the mediation model were 
Table 2 Univariate analysis of factors associated with mother-to-child transmission of HIV-1 at 6 weeks and at 6 months of life

\begin{tabular}{|c|c|c|c|c|c|c|c|c|}
\hline \multirow[t]{2}{*}{ Variables } & \multicolumn{4}{|c|}{ Infant HIV-1 status at 6 weeks } & \multicolumn{4}{|c|}{ Infant HIV-1 status at 6 months } \\
\hline & $\mathbf{n}$ & HIV-(\%) & HIV + (\%) & P-value & $\mathrm{N}$ & HIV-(\%) & HIV + (\%) & P-value \\
\hline \multicolumn{9}{|l|}{ Mother's age, years } \\
\hline$<=24$ & 202 & 95.5 & 4.5 & 0.317 & 202 & 94.6 & 5.4 & 0.117 \\
\hline$>24$ & 477 & 97.1 & 2.9 & & 473 & 97.0 & 3.0 & \\
\hline \multicolumn{9}{|l|}{ Marital status } \\
\hline married & 562 & 97.7 & 2.3 & 0.001 & 559 & 97.5 & 2.5 & 0.000 \\
\hline unmarried & 117 & 91.5 & 8.5 & & 116 & 90.5 & 9.5 & \\
\hline \multicolumn{9}{|l|}{ Education } \\
\hline none/primary & 509 & 96.5 & 3.5 & 0.710 & 508 & 96.3 & 3.7 & 0.930 \\
\hline secondary/university & 170 & 97.1 & 2.9 & & 167 & 96.4 & 3.6 & \\
\hline \multicolumn{9}{|l|}{ Wealth } \\
\hline poorest & 175 & 94.3 & 5.7 & 0.328 & 174 & 94.3 & 5.7 & 0.459 \\
\hline second & 99 & 98.0 & 2.0 & & 99 & 98.0 & 2.0 & \\
\hline middle & 143 & 97.2 & 2.8 & & 143 & 97.2 & 2.8 & \\
\hline fourth & 145 & 96.6 & 3.4 & & 144 & 95.8 & 4.2 & \\
\hline richest & 117 & 98.3 & 1.7 & & 115 & 97.4 & 2.6 & \\
\hline \multicolumn{9}{|l|}{ Parity } \\
\hline primipara & 146 & 93.2 & 6.8 & 0.009 & 144 & 91.7 & 8.3 & 0.001 \\
\hline multiparous & 533 & 97.6 & 2.4 & & 531 & 97.6 & 2.4 & \\
\hline \multicolumn{9}{|c|}{ Disclosed HIV status to partner } \\
\hline Yes & 551 & 98.2 & 1.8 & 0.000 & 550 & 97.8 & 2.2 & 0.000 \\
\hline No & 128 & 89.8 & 10.2 & & 125 & 89.6 & 10.4 & \\
\hline \multicolumn{9}{|l|}{ Place of delivery } \\
\hline home & 20 & 90.0 & 10.0 & 0.097 & 20 & 90.0 & 10.0 & 0.130 \\
\hline facility & 659 & 96.8 & 3.2 & & 655 & 96.5 & 3.5 & \\
\hline \multicolumn{9}{|l|}{ Sex of the infant } \\
\hline male & 335 & 96.7 & 3.3 & 0.883 & 332 & 96.4 & 3.6 & 0.904 \\
\hline female & 344 & 96.5 & 3.5 & & 343 & 96.2 & 3.8 & \\
\hline \multicolumn{9}{|c|}{ Type of feeding during first 6 months of life } \\
\hline exclusive breastfeeding & 585 & 96.8 & 3.2 & 0.070 & 581 & 96.6 & 3.4 & 0.002 \\
\hline artificial feeding & 80 & 97.5 & 2.5 & & 80 & 97.5 & 2.5 & \\
\hline mixt feeding & 14 & 85.7 & 14.3 & & 14 & 78.6 & 21.4 & \\
\hline \multicolumn{9}{|l|}{ Mode of delivery } \\
\hline vaginal/instrument assisted & 558 & 96.4 & 3.6 & 0.542 & 554 & 96.0 & 4.0 & 0.431 \\
\hline cesarean section & 121 & 97.5 & 2.5 & & 121 & 97.5 & 2.5 & \\
\hline \multicolumn{9}{|c|}{ Hemoglobin during pregnancy } \\
\hline$<11 \mathrm{~g} / \mathrm{dl}$ & 180 & 93.3 & 6.7 & 0.005 & 179 & 93.9 & 6.1 & 0.044 \\
\hline$>=11 \mathrm{~g} / \mathrm{dl}$ & 499 & 97.8 & 2.2 & & 496 & 97.2 & 2.8 & \\
\hline \multicolumn{9}{|l|}{ Type of ARV treatment } \\
\hline prophylactic & 352 & 97.4 & 2.6 & 0.215 & 350 & 96.9 & 3.1 & 0.423 \\
\hline curative & 327 & 95.7 & 4.3 & & 325 & 95.7 & 4.3 & \\
\hline \multicolumn{9}{|c|}{ Duration of ARV treatment prior to delivery } \\
\hline less than 6 weeks & 153 & 93.5 & 6.5 & 0.014 & 152 & 94.1 & 5.9 & 0.100 \\
\hline 6 weeks or more & 526 & 97.5 & 2.5 & & 523 & 96.9 & 3.1 & \\
\hline
\end{tabular}


Table 2 Univariate analysis of factors associated with mother-to-child transmission of HIV-1 at 6 weeks and at 6 months of life (Continued)

\begin{tabular}{|c|c|c|c|c|c|c|c|c|}
\hline$\overline{\text { CD4 count }}$ & & & & & & & & \\
\hline$<350$ cells $/ \mathrm{mm}^{3}$ & 263 & 94.3 & 5.7 & 0.009 & 261 & 94.3 & 5.7 & 0.028 \\
\hline$>=350$ cells $/ \mathrm{mm}^{3}$ & 416 & 98.1 & 1.9 & & 414 & 97.6 & 2.4 & \\
\hline \multicolumn{9}{|l|}{ Viral load } \\
\hline$<1000$ copies/ml & 517 & 98.6 & 1.4 & 0.000 & 514 & 98.1 & 1.9 & 0.000 \\
\hline$>=1000$ copies $/ \mathrm{ml}$ & 162 & 90.1 & 9.9 & & 161 & 90.7 & 9.3 & \\
\hline
\end{tabular}

Muhima health centre cohort, Kigali/Rwanda, 2007 - 2010.

satisfied (Figure 1) [20,23]. This is considered as a perfect mediation model as the independent variable (marital status) has shown no effect on the dependent variable (infant HIV-1 status) when the mediator is controlled (HIV status disclosure). Unmarried women infected with HIV-1 have higher risk of HIV-1 mother-to-child transmission with undisclosed HIV status, as a mediator. The mediator variable explains how external physical events (independent variable) take on internal psychological significance [21-23].

\section{Viral load}

The level of HIV-1 RNA in maternal plasma remains the major biological predictor of both early and late mother-to-child transmission of the virus. HIVinfected individuals who maintain increased levels of HIV-1 RNA load, extended high viremics, can transmit virus at higher rates. Combinatorial ART decreases HIV replication, thus reducing rates of virus transmission $[35,36]$.

In addition, existing studies have shown that, for women receiving HAART for prevention of HIV-1 transmission, breast milk HIV-1 RNA level is associated with systemic viral burden [37].

The total viral suppression (below 40 copies $/ \mathrm{mL}$ for this study) provides the most protective effect against mother-to-child transmission of HIV-1 [38,39].

Achieving viral suppression by delivery to prevent MTCT depends on maternal viral load baseline level and time of HAART initiation during pregnancy as shown by a UK study findings. This suggest that with a viral load of more than 10,000 copies $/ \mathrm{mL}$ and especially with a viral load more than 100,000 copies $/ \mathrm{mL}$, the probability of achieving either less than 50 copies $/ \mathrm{mL}$ by the time of delivery is compromised by delaying initiation of short-term highly active antiretroviral therapy beyond 20.4 weeks gestation [40].

\section{Breastfeeding}

Like many studies investigating feeding choices for HIV-1 exposed infants in breastfeeding populations, the Muhima cohort study results show that exclusive breastfeeding was associated with a lower risk of postnatal transmission at 6 months, compared with mixed feeding, but it does not eliminate risk. The only method known to completely eliminate breastfeeding associated HIV transmission is not to breastfeed. This is recommended in settings in which infant replacement feeding is affordable and sustainable [41-44].

A prospective study in Zimbabwe with 14,110 mothernewborn pairs followed for 2 years showed that early mixed feeding, when compared with early breastfeeding, was associated with a 2.5 fold (95CI 1.3 to 4.8 ) greater risk of HIV infection or death at 18 months [45].

Breast milk protective mechanisms include factors that have the ability to inactivate HIV and/or binding to the infant mucosa and/or target cells. Milk also contains many anti-inflammatory factors that would limit viral replication within milk, as well as maintain the integrity of both the mammary (reducing transmissibility) and the infant mucosal epithelia (reducing susceptibility) [46].

The WHO infant feeding guidelines in the context of HIV have been revised to ensure balance between HIV prevention with protection from other causes of child mortality. They recommend that national or subnational authorities should decide whether health services will principally counsel and support HIV infected mothers to either avoid all breastfeeding or to breastfeed and receive infant or maternal antiretroviral prophylaxis [43].

In Rwandan general population, exclusive breastfeeding is the norm. As reported by Rwanda Demographic and Health Survey 2010 results, eighty-five percent of children under age of 6 months are exclusively breastfed, 2 percent are given milk and plain water, 7 percent get breast milk and non-milk 
Table 3 Multivariable logistic regression analysis of risk factors associated with mother-to-child transmission of HIV at 6 weeks and at 6 months of life

\begin{tabular}{|c|c|c|}
\hline Variables & $\begin{array}{l}\text { HIV infection } \\
\text { at } 6 \text { weeks } \\
(1) \\
\text { adjusted OR } \\
{[95 \% \mathrm{Cl}]}\end{array}$ & $\begin{array}{l}\text { HIV infection } \\
\text { at } 6 \text { months } \\
(2) \\
\text { adjusted OR } \\
{[95 \% \mathrm{Cl}]} \\
\end{array}$ \\
\hline \multicolumn{3}{|l|}{ Mother's age } \\
\hline$<=24$ & $1.22[0.41-3.64]$ & $1.43[0.53-3.89]$ \\
\hline$>24$ & 1 & 1 \\
\hline \multicolumn{3}{|l|}{ Marital status } \\
\hline not currently married & $1.42[0.42-4.79]$ & $1.55[0.49-4.90]$ \\
\hline currently married & 1 & 1 \\
\hline \multicolumn{3}{|l|}{ Education attainment } \\
\hline none/primary & $1.09[0.29-4.08]$ & $1.09[0.33-3.63]$ \\
\hline secondary/university education & 1 & 1 \\
\hline \multicolumn{3}{|l|}{ Wealth index } \\
\hline poorest & $2.07[0.31-14.01]$ & $1.37[0.27-7.01]$ \\
\hline second & $0.77[0.07-8.16]$ & $0.39[0.05-3.44]$ \\
\hline middle & $0.82[0.11-5.90]$ & $0.53[0.09-2.94]$ \\
\hline fourth & $1.33[0.21-8.32]$ & $1.05[0.23-4.91]$ \\
\hline richest & 1 & 1 \\
\hline \multicolumn{3}{|l|}{ Parity } \\
\hline primiparous & $1.97[0.65-5.94]$ & $2.33[0.84-6.41]$ \\
\hline multiparous & 1 & 1 \\
\hline \multicolumn{3}{|l|}{ Disclosed HIV status to partner } \\
\hline No & $4.68^{* *}[1.39-15.77]$ & $3.41^{* *}[1.09-10.65]$ \\
\hline Yes & 1 & 1 \\
\hline \multicolumn{3}{|l|}{ Place of delivery } \\
\hline home & $2.98[0.42-21.17]$ & $2.21[0.33-14.88]$ \\
\hline health facility & 1 & 1 \\
\hline \multicolumn{3}{|l|}{ child's sex } \\
\hline Male & $1.27[0.49-3.34]$ & $1.21[0.49-2.98]$ \\
\hline Female & 1 & 1 \\
\hline \multicolumn{3}{|l|}{$\begin{array}{l}\text { Type of feeding for the child } \\
\text { during first } 6 \text { months of life }\end{array}$} \\
\hline mixed feeding & $5.5[0.40-74.82]$ & $9.64^{*}[0.96-96.62]$ \\
\hline artificial feeding & $2.45[0.39-15.24]$ & $1.99[0.36-11.10]$ \\
\hline exclusive breastfeeding & 1 & 1 \\
\hline
\end{tabular}

\begin{tabular}{lcc}
\hline vaginal/instrument assisted & $0.66[0.17-2.57]$ & $0.91[0.24-3.40]$ \\
cesarean section & 1 & 1 \\
Hemoglobin & &
\end{tabular}

\begin{tabular}{lcc}
\hline$<11 \mathrm{~g} / \mathrm{dl}$ & $2.58^{*}[0.90-7.40]$ & $1.73[0.65-4.62]$ \\
$>=11 \mathrm{~g} / \mathrm{dl}$ & 1 & 1
\end{tabular}

Type of ARV treatment received

\begin{tabular}{lcc}
\hline prophylactic & $1.82[0.38-8.73]$ & $1.79[0.43-7.41]$ \\
curative & 1 & 1
\end{tabular}

Table 3 Multivariable logistic regression analysis of risk factors associated with mother-to-child transmission of HIV at 6 weeks and at 6 months of life (Continued)

\begin{tabular}{lcc}
\hline $\begin{array}{l}\text { duration of ARV prophylaxis/ } \\
\text { treatment }\end{array}$ & & \\
\hline less than 6 weeks & $2.24[0.81-6.16]$ & $1.35[0.51-3.57]$ \\
6 weeks or more & 1 & 1 \\
CD4 count & $4.83^{*}[0.98-23.90]$ & $3.82^{*}[0.92-15.94]$ \\
\hline$<350$ cellules $/ \mathrm{mm}^{3}$ & 1 & 1 \\
$>=350$ cellules $/ \mathrm{mm}^{3}$ & & \\
Viral load & $7.30^{* * *}[2.65-20.08]$ & $4.60^{* * *}[1.84-11.49]$ \\
$>=1000$ copies $/ \mathrm{ml}$ & 1 & 1 \\
$<1000$ copies $/ \mathrm{ml}$ & 679 & 675 \\
Observations &
\end{tabular}

*** $p<0.01,{ }^{* *} p<0.05,{ }^{*} p<0.1$.

The following variables were considered for inclusion in the logistic regression model: mother's age; marital status; wealth; parity; HIV status disclosure to partner; place of delivery; mode of delivery; child sex; infant feeding choice; hemoglobin; type of ARV treatment received; duration of ARV prophylaxis/ treatment; CD4 count and viral load (HIV-1 RNA).

Muhima health centre cohort, Kigali/Rwanda, 2007 - 2010.

liquids, and 3 percent take other types of milk in addition to breast milk [6]. With regard to mixed feeding in the context of HIV/AIDS in Rwanda, an evaluation of infant feeding and young child feeding practices reported high prevalence of exclusive breastfeeding with weaning at 4-6 months. The author found no indication that mothers who mixed fed did so because they believed their breast milk was insufficient. This finding suggest that it should be possible to achieve even higher rates of exclusive breastfeeding if mothers are educated about the need to avoid feeds other than breast milk and, if they are supported, to have faith that their milk is adequate for their babies, even if their health and nutritional status are less than ideal [44].

\section{CD4 count}

Maternal CD4+ count has been used as an indicator to assess eligibility for antiretroviral treatment \& prophylaxis for prevention of HIV-1 mother-to-child transmission and low CD4+ lymphocyte count was found associated with increased mother-to-child transmission risk [47-53]. Available studies have also shown that CD4 count increases with the use of triple-drug combination therapy [54].

\section{Hemoglobin}

Studies conducted in Sub-Saharan Africa that have found low maternal hemoglobin level $(<11 \mathrm{~g} / \mathrm{dl})$ during pregnancy, as a risk factor for HIV-1 motherto-child transmission [55-57]. Anemia is a common clinical finding in HIV-infected patients. In these 
patients, many factors may contribute to the development of anemia, including nutritional deficiencies, opportunistic infections, AIDS-related malignancies, drug treatment and a direct effect of HIV on the bone marrow. Iron maldistribution may increase susceptibility to opportunistic infections and accelerate disease progression [57].

This study has some limitations. The self-reporting as an approach to provide survey data is likely to introduce specific biases for factors such as infant feeding practices, mutual disclosure of HIV status and individual socioeconomic characteristics. Although Muhima study findings corroborate those from existing literature about major risk factors for mother-to-child transmission of HIV-1 in breastfeeding populations, it was only conducted in one of the 30 Rwanda districts and located in urban area. For the results to be generalizable to the entire country there would be need for larger studies.

\section{Conclusion}

In 679 mother - infant pairs followed at Muhima health Centre (Rwanda), the most relevant factors independently associated with increased risk of mother - to - child transmission of HIV-1 included non-disclosure of HIV status to partner and high HIV-1 RNA. Members of this cohort also showed socioeconomic inequalities, with unmarried status carrying higher risk of undisclosed HIV status that, as a mediator, was associated with higher risk of MTCT. Such findings suggest that HIV status disclosure to partner \& HIV-1 RNA level are key entry points for reducing HIV-1 mother-to-child transmission in Rwanda. And more specifically, the monitoring of HIV-1 RNA level might be considered as a routinely used test to assess the risk of transmission with the goal of achieving viral suppression as critical for elimination of transmission, particularly in breastfeeding populations. In addition, further research is needed to identify most effective interventions to get optimal mutual disclosure of HIV status for Rwanda PMTCT services \& clients.

\footnotetext{
Abbreviations

AIDS: Acquired immunodeficiency syndrome; ARV: Antiretroviral; CD4: T-helper cells; Cl: Confidence interval; DNA: Deoxyribonucleic Acid; HAART: Highly active antiretroviral therapy; HIV: Human immunodeficiency virus; OR: Odds ratio; PCR: Polymerase chain reaction; PMTCT: Prevention of mother-to-child transmission; RNA: Ribonucleic acid; WHO: World Health Organization.
}

\section{Competing interests}

Authors declare no competing interests.

\section{Authors' contributions}

MB supervised the study and wrote the paper. JDDB \& JM assisted with data collection, entry and analysis. CPH contributed to the study design, data analysis and reviewed the manuscript critically for important intellectual content. All authors read and approved the final manuscript.

\section{Acknowledgements}

The authors thank the teams from the Rwanda Ministry of Health and Muhima health centre who have provided support for data collection as well as The National Reference Laboratory of Rwanda that conducted viral load tests with the financial support from EGPAF-Rwanda.

\section{Author details}

${ }^{1}$ World Health Organization Department of Maternal, Newborn, Child and Adolescent Health, 20, Avenue Appia, CH - 1211, Geneva 27, Switzerland. ${ }^{2}$ CAMRIS International, 6931 Arlington Road, Suite 575, Bethesda, MD 20814, USA. ${ }^{3}$ Department of Obstetrics \& Gynecology, Rwanda Biomedical Center/ King Faisal Hospital, P.O. Box 2534, Kigali, Rwanda. ${ }^{4}$ Université Libre de Bruxelles/Ecole de Santé Publique, Route de Lennik 808, 1070, Bruxelles, Belgium.

Received: 26 November 2012 Accepted: 18 February 2013 Published: 28 February 2013

\section{References}

1. Ruton H, Mugwaneza P, Shema N, Lyambabaje A, Bizimana JDD, Tsague L, Nyankesha E, Wagner CM, Mutabazi V, Nyemazi JP, Nsanzimana S, Karema C, Binagwaho A: HIV-free survival among nine-to 24-month old children born to HIV-positive mothers in the Rwandan national PMTCT programme: a community-based household survey. J Int AIDS Soc 2012, 15:4.

2. Lepage $P$, Van de Perre $P$, Msellati $P$, Hitimana D, Simonon A, Van Goethem C, Mukamabano B, Karita E, Stevens AM, Mathieu G, Salamon R, Dabis F: Mother-to-child transmission of Human Immunodeficiency Virus Type 1 (HIV-1) and its determinants: a cohort study in Kigali, Rwanda. Am J Epidemiol 1993, 137(6):589-599.

3. UNAIDS: World AIDS day report, 2011. http://www.unaids.org/en/media/ unaids/contentassets/documents/unaidspublication/2011/ JC2216_WorldAIDSday_report_2011_en.pdf.

4. Rwanda National Institute of Statistics: Statistical Yearbook, 2011. http:// www.statistics.gov.rw/publications/rwanda-statistical-yearbook-2011.

5. Rwanda National Institute of Statistics, Ministry of Health and ORC Macro Calverton, Maryland USA: Rwanda Demographic and Health Survey 2010: final report. http://www.statistics.gov.rw/publications/demographic-and-healthsurvey-2010-final-report.

6. Logie DE, Rowson M, Ndagije F: Innovations in Rwanda's health system: looking to the future. Lancet 2008, 372(9634):256-261.

7. United Nations General Assembly Special Session on HIV and AIDS: Rwanda AIDS country progress, 2008-2009. March 2010. http://data.unaids.org/pub/ Report/2010/rwanda_2010_country_progress_report_en.pdf.

8. Peltier CA, Ndayisaba GF, Lepage P, Van Griensven J, Leroy V, Pharm CO, Ndimubanzi PC, Courteille O, Arendt V: Breastfeeding with maternal antiretroviral therapy or formula feeding to prevent HIV postnatal mother-to-child transmission in Rwanda. AIDS 2009, 23(18):2415-2423.

9. WHO, UNICEF, UNFPA and UNAIDS: Towards the elimination of mother-to-child transmission of HIV. World Health Organization; 2011. http://www.who.int/ hiv/pub/mtct/elimination_report/en.

10. Dabis F, Bequet L, Ekouevi DK, Viho I, Rouet F, Horo A, Sakarovitch C, Bequet R, Fassinou P, Dequae-Merchadou L, Welffens-Ekra C, Rouzioux C, Leroy V, ANRS 1201/1202 DITRAME PLUS Study Group: Field efficacy of zidovudine, lamivudine and single-dose nevirapine to prevent peripartum HIV transmission. AIDS 2005, 19(3):309-318.

11. European Collaborative Study: Mother-to-child transmission of HIV infection in the era of highly active antiretroviral therapy. Clin Infect Dis 2005, 40(3):458-465.

12. Shah I: Is elective caesarian section really essential for prevention of mother to child transmission of HIV in the era of antiretroviral therapy and abstinence of breast feeding? J Tropical Pediatrics March 2006, 52(3):163-165.

13. Commission on Social Determinants of Health: Closing the gap in a generation: health equity through action on the social determinants of health. Final report of the Commission on Social Determinants of Health. Geneva: World Health Organization; 2008.

14. Hennekens HC, Buring EJ: Epidemiology in Medicine. Firstth edition. USA; 1987. 
15. Spear GT, Zariffard MR, Chen HY, Anzinger JJ, Anastos K, Rusine J, Gatabazi J, French AL, Cohen M, Landay AL: Positive association between HIV RNA and IL6 in the genital tract of Rwandan women. AIDS Res Hum Retroviruses 2008, 24(7):973-976. doi:10.1089/aid.2008.0004

16. Fischer A, Lejczak C, Lambert C, Servais J, Makombe N, Rusine J, Staub T, Hemmer R, Schneider F, Schmit JC, Arendt V: Simple DNA extraction method for dried blood spots and comparison of two PCR assays for diagnosis of vertical Human Immunodeficiency Virus Type 1 transmission in Rwanda. J Clin Microbio/ 2004, 42(1):16-20.

17. Van Dyke RB: Mother-to-child transmission of HIV-1 in the era prior to the availability of combination antiretroviral therapy: the role of drugs of abuse. Life Sci 2011, 88(21-22):922-925. doi:10.1016/j.lfs.2011.03.006.

18. Scavalli CP, Mandelbrot L, Berrebi A, Batallan A, Cravello L, Pannier E, Hamrene K, Ciraru-Vigneron N, Faye A, Warszawski J, ANRS EPF: Twin pregnancy as a risk factor for mother-to-child transmission of HIV-1: trends over 20 years. AIDS 2007, 21(8):993-1002.

19. ORC Macro Calverton, Maryland USA: The Demographic and Health Survey wealth index. http://www.measuredhs.com/publications/publication-cr6comparative-reports.cfm.

20. Baron RM, Kenny DA: The moderator-mediator variable distinction in social psychological research: conceptual, strategic and statistical considerations. J Pers Soc Psychol 1986, 51(6):1173-1182.

21. Wu AD, Zumbo BD: Understanding and using mediators and moderators. Soc Indic Res 2008, 87:367-392. doi:10.1007/s11205-007-9143-1.

22. Brauer M: L'identification des processus médiateurs dans la recherche en psychologie. Annee Psychol 2000, 100:661-681.

23. Cole SW, Kemeny ME, Fahey JL, Zack JA, Naliboff BD: Psychological risk factors for HIV pathogenesis: mediation by the autonomic nervous system. Soc Biological Psychiatry. http://www.sciencedirect.com/science/ article/pii/S0006322302018887.

24. Ahmad N: Molecular mechanisms of HIV-1 mother-to-child transmission and infection in neonatal target cells. Life Sci 2011, 88(21-22):980-986. doi:10.1016/j. Ifs.2010.09.023.

25. Goetghebuer T, Haelterman E, Marvillet I, Barlow P, Hainaut M, Salameh A Ciardelli R, Gerard M, Levy J: Vertical transmission of HIV in Belgium: a 1986-2002 retrospective analysis. Eur J Pediatr 2009, 168(1):79-85.

26. Mucheto P, Chadambuka A, Shambira G, Tshimanga M, Gombe N, Nyamayaro W: Determinants of nondisclosure of HIV status among women attending the prevention of mother to child transmission programme, Makonde district, Zimbabwe, 2009. Pan Afr Med J 2011, 8:51.

27. Osinde MO, Kakaire O, Kaye DK: Factors associated with disclosure of HIV serostatus to sexual partners of patients receiving HIV care in Kabale, Uganda. Int J Gynaecol Obstet 2012, 118(1):61-64.

28. Nachega JB, Morroni C, Zuniga JM, Sherer R, Beyrer C, Solomon S, Schechter M, Rockstroh J: HIV-Related Stigma, Isolation, Discrimination, and Serostatus Disclosure: A Global Survey of 2035 HIV-Infected Adults. J Int Assoc Physicians AIDS Care (Chic) 2012, 11(3):172-178.

29. Jasseron C, Mandelbrot L, Dollfus C, Trocmé N, Tubiana R, Teglas JP, Faye A, Rouzioux C, Blanche S, Warszawski J: Non-Disclosure of a Pregnant Woman's HIV Status to Her Partner is Associated with Non-Optimal Prevention of Mother-to-Child Transmission. AIDS Behav 2013, 17(2):488-497. doi:10.1007/s10461-011-0084-y.

30. Olagbuji BN, Ezeanochie MC, Agholor KN, Olagbuji YW, Ande AB, Okonofua FE: Spousal disclosure of HIV serostatus among women attending antenatal care in urban Nigeria. J Obstet Gynecol 2011, 31(6):486-488

31. Mofenson LM: Prevention in neglected subpopulations: prevention of mother-to-child transmission of HIV infection. Clin Infect Dis 2010, 50(Suppl 3):S130-S148.

32. Obermeyer CM, Baijal P, Pegurri E: Facilitating HIV disclosure across diverse settings: a review. Am J Public Health 2011, 101(6):1011-1023.

33. Patel R, Ratner J, Gore-Felton C, Kadzirange G, Woelk G, Katzenstein D: HIV disclosure patterns, predictors, and psychosocial correlates among HIV positive women in Zimbabwe. AIDS Care 2012, 24(3):358-368.

34. Horvath T, Madi BC, luppa IM, Kennedy GE, Rutherford G, Read JS: Interventions for preventing late postnatal mother-to-child transmission of HIV. Cochrane Database Syst Rev 2009, 1:CD006734.

35. Novitsky V, Essex M: Using HIV viral load to guide treatment-for -prevention interventions. Curr Opin HIV AIDS 2012, 7(2):117-124.
36. Mmiro FA, Aizire J, Mwatha AK, Eshleman SH, Donnell D, Fowler MG, Nakabiito C, Musoke PM, Jackson JB, Guay LA: Predictors of early and late mother-to-child transmission of HIV in a breastfeeding population: HIV network for prevention trials 012 experience, Kampala, Uganda. J Acquir Immune Defic Syndr 2009, 52(1):32-39.

37. Slyker JA, Chung MH, Lehman DA, Kiarie J, Kinuthia J, Holte S, Tapia K, Njiri F, Overbaugh J, John-Stewart G: Incidence and correlates of HIV-1 RNA detection in the breast milk of women receiving HAART for the prevention of HIV-1 transmission. PLoS One 2012, 7(1):e29777.

38. Nielsen-Saines $K$, et al: Three postpartum antiretroviral regimens to prevent intrapartum HIV infection. N Engl J Med 2012, 366:2368-2379.

39. Joao EC, Gouvêa MI, Menezes JA, Sidi LC, Cruz ML, Berardo PT, Ceci L, Cardoso CA, Teixeira Mde L, Calvet GA, Matos HJ: Factors associated with viral load suppression in HIV-infected pregnant women in Rio de Janeiro, Brazil. Int J STD AIDS 2012, 23(1):44-47.

40. Read PJ, Mandalia S, Khan P, Harrisson U, Naftalin C, Gilleece Y, Anderson J, Hawkins DA, Taylor GP, de Ruiter A, London HIV Perinatal Research Group: When should HAART be initiated in pregnancy to achieve an undetectable HIV viral load by delivery? AIDS 2012, 26(9):1095-1103.

41. Volmink J, Marais B: HIV: mother-to-child transmission. Clin Evid (Online) 2008, pii:0909.

42. Aldrovandi $G M$, Kuhn $L$ : What infants and breasts can teach us about natural protection from HIV infection. J Infect Dis 2010, 202(Supplement 3). doi:10.1086/655972.

43. Guidelines on HIV and infant feeding, 2010. Principles and recommendations for infant feeding in the context of HIV and a summary of evidence. Geneva: World Health Organization; 2010. http://www.who.int/ maternal_child_adolescent/documents/9789241599535/en/.

44. Thiaru L: Update: Infant and young child feeding practices in the context of HIV/AIDS in Rwanda. Program for Appropriate Technology in Health; 2007. http://www.path.org/publications/files/MCHN_IYCF_update.pdf.

45. Iliff PJ, Piwoz EG, Tavengwa NV, Zunguza CD, Marinda ET, Nathoo KJ, Moulton LH, Ward BJ, Humphrey JH, ZVITAMBO study group: Early exclusive breastfeeding reduces the risk of postnatal HIV-1 transmission and increases HIV-free survival. AIDS 2005, 19(7):699-708.

46. Moodley D, Esterhuizen T, Reddy L, Moodley P, Singh B, Ngaleka L, Govender D: Incident HIV infection in pregnant and lactating women and its effect on mother-to-child transmission in South Africa. J Infect Dis 2011, 203(9):1231-1234.

47. Tchendjou P, Same-Ekobo C, Nga A, Tejiokem M, Kfutwah A, Nlend AN, Tsague L, Bissek AC, Ekoa D, Orne-Gliemann J, Rousset D, Pouillot R, Dabis F: Effectiveness of multidrug antiretroviral regimens to prevent mother-to -child transmission of HIV-1 in routine public health services in Cameroon. PLoS One 2010, 5(4):e10411.

48. Sturt AS, Dokubo EK, Sint T: Antiretroviral therapy (ART) for treating HIV infection in ART-eligible pregnant women. Cochrane Database Syst Rev 2010, 3:CD008440.

49. Tubiana R, Le Chenadec J, Rouzioux C, Mandelbrot L, Hamrene K, Dollfus C, Faye A, Delaugerre C, Blanche S, Warszawski J: Factors associated with mother-to-child transmission of HIV-1 despite a maternal viral load $<500$ copies/ml at delivery: a case-control study nested in the French perinatal cohort (EPF-ANRS CO1). Clin Infect Dis 2010, 50(4):585-596.

50. Toro PL, Katyal M, Carter RJ, Myer L, El-Sadr WM, Nash D, Abrams EJ, MTCTPlus Initiative: Initiation of antiretroviral therapy among pregnant women in resource-limited countries: CD4+ cell count response and program retention. AIDS 2010, 24(4):515-524.

51. Becquet R, Ekouevi DK, Arrive E, Stringer JS, Meda N, Chaix ML, Treluyer JM, Leroy $V$, Rouzioux C, Blanche S, Dabis F: Universal antiretroviral therapy for pregnant and breast-feeding HIV-1-infected women: towards the elimination of mother-to-child transmission of HIV-1 in resource-limited settings. Clin Infect Dis 2009, 49(12):1936-1945.

52. Hansmann A, Schim van der Loeff MF, Kaye $S$, Awasana AA, Sarge-Njie R, O'Donovan D, Ariyoshi K, Alabi A, Milligan P, Whittle HC: Baseline plasma viral load and CD4 cell percentage predict survival in HIV-1- and HIV-2-infected women in a community-based cohort in the Gambia. J Acquir Immune Defic Syndr 2005, 38(3):335-341.

53. Simpkins EP, Siberry GK, Hutton N: Thinking about HIV infection. Pediatr Rev 2009, 30(9):337-348. quiz 349.

54. Mehta S, Manji KP, Young AM, Brown ER, Chasela C, Taha ET, Read JS, Goldenberg RL, Fawzi WW: Nutritional indicators of adverse pregnancy 
outcomes and mother-to-child transmission among HIV-infected women. Am J Clin Nutr 2008, 87(6):1639-1649.

55. Duri K, Gumbo FZ, Kristiansen Kl, Kurewa NE, Mapingure MP, Rusakaniko S, Chirenje MZ, Muller F, Stray-Pedersen B: Antenatal HIV-1 RNA load and timing of mother to child transmission; a nested case-control study in a resource poor setting. Virol I 2010, 7:176.

56. Bobat R, Coovadia H, Coutsoudis A, Moodley D: Determinants of motherto-child transmission of human immunodeficiency virus type 1 infection in a cohort from Durban, South Africa. Pediatr Infect Dis J 1996, 15(7):604-610.

57. Wisaksana $X$, et al: Anemia and iron homeostasis in a cohort of HIV-infected patients in Indonesia. BMC Infect Dis 2011, 11:213.

doi:10.1186/0778-7367-71-4

Cite this article as: Bucagu et al: Socio-economic, clinical and biological risk factors for mother - to - child transmission of HIV-1 in Muhima health centre (Rwanda): a prospective cohort study. Archives of Public Health 2013 71:4.

\section{Submit your next manuscript to BioMed Central and take full advantage of:}

- Convenient online submission

- Thorough peer review

- No space constraints or color figure charges

- Immediate publication on acceptance

- Inclusion in PubMed, CAS, Scopus and Google Scholar

- Research which is freely available for redistribution 